\title{
Standards for two-year college
}

\section{learning resources programs: A draft}

\author{
Prepared by the AECT-ACRL Joint Committee \\ J. O. Wallace and Dan Koenig, Co-chairs
}

\section{A hearing on these proposed standards will be held in Dallas on June 23, 2:00-5:30 p.m.}

$\mathbf{T}$ hese standards apply to two-year or three-year academic institutions awarding an associate degree or certificate. They are intended to assist in evaluating and developing learning resources programs. Upon approval by the Association for Educational Communications and Technology and the Association of College and Research Libraries, the document will replace Guidelines for Two-Year College Learning Resources Programs (Revised) and Quantitative Standards for Two-Year Learning Resources Programs.

Two-year colleges make a significantly different contribution than other academic institutions. The public institutions, because of community control, are generally more responsive to local needs. Moderate costs and open access allows greater flexibility to students who would not otherwise be able to attend college. Emphases on vocational and adult programs and continuing education provide employable skills to many adult students through responsiveness to changing vocational needs. At the same time, while allowing for remedial work to remove deficiencies, academic programs in private and community colleges parallel education in the arts and sciences in four-year institutions. Reflecting the combination of availability of opportunity and expectation of excellence in performance, more than half of the students pursuing higher education are enrolled in community, technical, and junior colleges nationwide.
The emphasis being made by the American Association of Community and Junior Colleges, especially for community colleges but also applicable to other two-year institutions, upon the building of communities, upon partnerships for learning, and upon excellence in teaching, requires resources and services which must be provided in accordance with these standards if the vision is to become reality (see American Association of Community and Junior Colleges, Building Communities, A Vision for a New Century: A Report of the Commission on the Future of Community Colleges, 1988).

In most two-year institutions an expanded concept of learning resources provides services to the college community. The term "learning resources" is applied in these standards to an organizational configuration which provides library and media materials and services and which can provide in addition various specialized services and perform other instructional responsibilities.

The structure and function of a library/learning resources center in each institution obviously has been determined by the role assigned within the institutional structure. This role must be consistent with the stated mission of the institution. It must also be related realistically to the institution's educational goals, curricula, size, and complexity, as well as the diversity of resources needed to accommodate different modes of learning.

As an organizational entity, the library/learning 
resources center with audiovisual responsibilities must provide the needed services in a technological environment which requires a substantial proportion of the campus budget. The combination of a number of related responsibilities under the title of a learning resources program is an effective and reasonable way to make the maximum use of the budget. This will expand the role and structure of the library/learning resources center, and, thereby, create an organizational unit which can provide all major instructional requirements needed to support the diverse educational programs.

\section{Standard one: Objectives}

1.0. The college shall develop a comprehensive statement of the mission of the learning resources program based on the nature and purposes of the institution.

Commentary. A clear and unambiguous statement of the role of the learning resources program is essential for accountability, administration, and review regardless of the organizational structure. Where there are public multi-college districts, separate mission statements should be developed for each college; multi-campus community college districts may either develop mission statements for each campus or prepare a comprehensive statement for the district-wide learning resources program components.

1.1. The mission statement shall be developed by the learning resources staff, in consultation with the widest possible representation of the college community; the statement or statements shall be endorsed by the governing board and shall be reviewed periodically.

Commentary. Assignment of responsibility to the learning resources staff for the development of the statement and for its utilization and review is appropriate.

1.2. The mission statement shall be used, along with institutional educational goals, in the annual planning process.

Commentary. The mission statement serves as a mirror for the evaluation of services and the projection of future needs. As such it becomes an integral part of the planning process.

1.3. All component units of the learning resources program, whether administered centrally or administered by other campus units, should be clearly defined.

Commentary. The learning resources program should include essential and basic library and media services as identified in the lists in Appendices A and $B$. There must be explicit understanding of the units which comprise the centralized services. The learning resources program may include other special components such as those listed in Appendix C. To standardize statistical data nationally, decentralized service units (those that report to other departments) should provide needed information about staff and expenditures for reporting to external agencies.

1.4. The learning resources program shall be an integral part of the instructional process of the institution.

Commentary. An effective learning resources program is and must be immediately and intimately involved in the entire educational program. There must be participation in curriculum development and approval because the identification and acquisition of resources to support any curricular changes requires time for planning services that may be needed, reading lists that could be provided, bibliographical instruction that must be given, and priorities on use of resources that should be established.

\section{Standard two: Organization}

2.0. The responsibilities and functions of the component units of the learning resources program within the institutional structure shall be clearly defined.

Commentary. The services provided are directly related to the quality of the educational program. When restricted to only a small number of basic services, the quality of the instructional program is inhibited; when too vaguely defined, valuable resources will be poorly utilized. Clarity in identifying functions and specificity in assigning responsibilities will provide a learning resources program potentially capable of meeting the needs of the college. Institutional manuals, procedures, and job descriptions confirm the status of the program.

2.1. The duties and responsibilities of the chief administrator of the learning resources program shall be clearly defined within the institutional structure.

Commentary. The chief administrator is responsible for administering the program and for providing leadership and direction so that the mission of the program is fulfilled. The administrator should report to the chief academic officer of the campus and should have the same administrative rank and status as others with similar institution-wide responsibilities; a title such as Dean of Instructional Services or of Learning Resources is appropriate.

2.2. The comprehensive learning resources program shall include a variety of services which are organized into functional units.

Commentary. The type of component units needed and included will vary from institution to institution and campus to campus. Some possibilities are: technical services, library services, media services, learning development, reprographic services, professional materials services, television production, graphics production, learning laboratories, and computer services. A listing of many of these can be found in the Appendices. Services which are not administratively under the supervision of the administrator should have a secondary relationship to the learning resources program to 
allow comprehensive planning and reporting and to avoid duplication.

2.3. The administrator and professional staff should be involved in all areas and at all levels of academic activities and institutional planning.

Commentary. The professional staff members should be involved in major college committees and participate in faculty affairs to the same extent as other faculty. The chief administrator must meet regularly with college administrators and department heads and, along with the professional staff members, must be involved in planning, implementing, and evaluating the instructional programs of the college.

2.4. Advisory committees should be formed to provide essential information to the staff and to serve as a link with users.

Commentary. Advisory committees are appointed, elected, or selected by the appropriate faculty, staff, or student constituencies. The development and evaluation of services can be more effective because of their responses.

2.5. Internal administration of the learning resources program should be based on staff participation in decisions on policies, procedures, and personnel.

Commentary. While the chief administrator is ultimately responsible, the basis for internal administration should be participatory governance through regular staff meetings and internal communication. The administrator is responsible for reporting to the staff about institutional plans, anticipated curriculum changes, and matters which will affect the internal effectiveness of the learning resources program; in turn the administrator will report concerns and recommendations of the learning resources staff to the college administrators.

Each professional and supportive staff member must be provided with a position description which clearly identifies the duties and responsibilities of the position and superior and subordinate relationships. Performance appraisal standards must be clearly defined and understood by all staff members. In addition to a general administrative manual, each unit may require a supplementary manual which provides policy and procedural statements, duty assignments, other organizational matters, and items of general information pertaining to its particular unit. Policy and procedures manuals covering internal library governance and operational activities shall be made available to all staff members.

\section{Standard three: Administration and staff}

3.0. Sufficient and qualified professional and support staff should be available to implement the services for which the program is responsible.

Commentary. Table A evaluates the requirements for adequate numbers of staff. The figures are for full-time positions at two levels, basic and excellent, based on full-time equivalent student en- rollments. The table does not include services listed in Appendix $\mathrm{C}$ as peripheral; if any of these services are assigned, additional staff will be needed in addition to the positions in the table. There is a direct relationship between staff, budget, and services. When staff level and funding level increase, the number of services possible will also increase; the reverse is also a dangerous possibility which should be avoided. Another factor affecting staff requirements is the ratio of FTE students to total enrollment; the higher the ratio the greater will be the need for additional staff beyond the formulas in Table A. If there is a regular summer session at the college, the positions in table A should be based on an eleven or twelve month equivalency.

3.1. The chief administrator shall be professionally trained and knowledgeable about all types of library and media materials and services.

Commentary. The training and experience of the chief administrator shall be as a librarian, a media specialist, or an information specialist with cross-training desirable. The minimal professional degree and prerequisite for the position is a master's degree in educational technology or library science. In order to interact with other administrators and the learning resources staff the chief administrator should demonstrate knowledge of effective management; to make decisions on costly new information services, the administrator should have some continuous experience with new technologies.

3.2. The professional staff shall have a graduate degree from an accredited institution and shall have faculty status, faculty benefits, and obligations.

Commentary. The complexity of the learning resources program may require considerable differentiated staffing by individuals with widely varied professional education and areas of specialization. All should have the same status and recognition as other instructional faculty; where faculty rank exists they should meet the same requirements for promotion and tenure as the other instructional faculty.

3.3. Professional staff should belong to library, media, and other appropriate associations, and professional development should be encouraged through support of attendance and participation in those local, state, and national organizations.

Commentary. The mark of a professional is not only performance on the job but also awareness of professional trends and technological developments learned at professional meetings and workshops, and from professional journals.

3.4. Technical and classified personnel should have appropriate specialized training or experience; classification, status, and salary should be equivalent to those provided for other institutional employees with similar qualifications.

Commentary. Requirements for training and experience needed should relate to the duties assigned. The relative importance of each type of 


\section{TABLE A}

Staffing Requirements for Services

(Excluding Those in Appendix $\mathrm{C}^{*}$ )

\begin{tabular}{|c|c|c|c|c|c|c|c|c|c|}
\hline \multirow[b]{2}{*}{$\begin{array}{c}\text { FTE } \\
\text { students }\end{array}$} & \multirow{2}{*}{$\begin{array}{l}\text { Administrators } \\
\text { Minimum \& } \\
\text { Excellent }\end{array}$} & \multicolumn{2}{|c|}{$\begin{array}{c}\text { Other } \\
\text { professionals }\end{array}$} & \multicolumn{2}{|c|}{ Technicians } & \multicolumn{2}{|c|}{ Other staff** } & \multicolumn{2}{|c|}{$\begin{array}{l}\text { TOTAL } \\
\text { STAFF }\end{array}$} \\
\hline & & $\begin{array}{l}\text { Mini- } \\
\text { mum }\end{array}$ & $\begin{array}{c}\text { Excel- } \\
\text { lent }\end{array}$ & $\begin{array}{l}\text { Mini- } \\
\text { mum }\end{array}$ & $\begin{array}{c}\text { Excel- } \\
\text { lent }\end{array}$ & $\begin{array}{l}\text { Mini- } \\
\text { mum }\end{array}$ & $\begin{array}{c}\text { Excel- } \\
\text { lent }\end{array}$ & $\begin{array}{l}\text { Mini- } \\
\text { mum }\end{array}$ & $\begin{array}{l}\text { Excel- } \\
\text { lent }\end{array}$ \\
\hline $\begin{array}{l}\text { Under } \\
200\end{array}$ & 1 & 0.5 & 2 & 1 & 2 & 1 & 2 & 3.5 & 7 \\
\hline $\begin{array}{l}200- \\
1,000\end{array}$ & 1 & 2 & 4 & 2 & 4 & 2 & 3 & 7 & 12 \\
\hline $\begin{array}{l}1,000- \\
3,000\end{array}$ & 1 & 3 & 5 & 3 & 6 & 3 & 6 & 10 & 18 \\
\hline $\begin{array}{l}3,000- \\
5,000\end{array}$ & 1 & 5 & 7 & 5 & 8 & 4 & 8 & 15 & 24 \\
\hline $\begin{array}{l}5,000- \\
7,000 \\
\end{array}$ & 1 & 7 & 9 & 7 & 12 & 6 & 11 & 21 & 33 \\
\hline $\begin{array}{l}7,000- \\
9,000\end{array}$ & 1 & 8 & 11 & 9 & 17 & 7 & 14 & 25 & 43 \\
\hline $\begin{array}{l}9,000- \\
11,000\end{array}$ & 1 & 10 & 15 & 11 & 20 & 9 & 17 & 31 & 53 \\
\hline $\begin{array}{l}11,000 \\
13,000\end{array}$ & 2 & 14 & 21 & 13 & 24 & 11 & 20 & 40 & 67 \\
\hline $\begin{array}{l}13,000- \\
15,000\end{array}$ & 2 & 16 & 24 & 16 & 28 & 13 & 24 & 47 & 78 \\
\hline $\begin{array}{l}15,000- \\
17,000\end{array}$ & 2 & 18 & 27 & 19 & 32 & 16 & 28 & 55 & 89 \\
\hline $\begin{array}{l}17,000- \\
19,000\end{array}$ & 2 & 20 & 30 & 21 & 36 & 18 & 32 & 61 & 100 \\
\hline
\end{tabular}

* Most will require 3 to 8 additional positions

** Secretaries, clerks, door attendants, lab aides, etc.

skill will vary across organizational levels. Supervisors should be selected on the basis of knowledge, experience, and human relations skills.

3.5. Student assistants are employed to perform a variety of tasks, but they should not be used in place of full or part-time staff personnel.

Commentary. The tasks performed by student assistants are usually of a routine nature. However, second-year students in some technical programs may bring skills of a more advanced nature which may supplement the skills of the staff. Student assistants are valuable sources of student opinion of services. They should be treated with respect by all other staff, encouraged to work responsibly on a job, and be given training for doing their tasks successfully.

3.6. The changing nature of the learning resources programs and technological changes which impact such programs mandate regular continuing education participation by all persons, professional and staff alike.
Commentary. Duty schedules should be flexible enough for staff to occasionally pursue further training during working hours. The institutional budget should include provision for travel to meetings and conferences, for registration fees, and released time for in-service training.

\section{Standard four: Budget}

4.0. The budget for the learning resources program should be developed within the mission statement as part of the institutional planning process; the annual objectives should be developed by the learning resources staff.

Commentary. The significance of the mission statement and the annual defined objectives forms the basis for the fiscal process for all of the budget except acquisitions. Stable funding for acquisitions based on the collection policy is necessary for effective service. Unfortunately consistent funding is the element least congenial to the development of 
annual objectives and is most affected by decreases; care must be taken to provide adequate information about the significance of stability.

4.1. An ample and stable budget should be based either on a percentage of educational and general budget totals for the institution as shown in Table B or on a full-time student equivalent dollar basis as shown in Table $\mathrm{C}$.

\section{TABLE B}

\section{Learning Resources Budget as Percent of Educational and General Expenditures}

\begin{tabular}{|c|c|c|}
\hline Size & Minimum & Excellent \\
\hline All & $5 \%$ & $9 \%$ \\
\hline
\end{tabular}

TABLE C

\section{Dollar Expenditure Per FTE Students for Learning Resources Other Than Salaries}

\begin{tabular}{|l|c|c|}
\hline \multicolumn{1}{|c|}{ FTE } & Minimum & Excellent \\
\hline Under 200 & 211 & 450 \\
$200-1,000$ & 225 & 400 \\
$1,000-3,000$ & 190 & 375 \\
$3,000-5,000$ & 190 & 375 \\
$5,000-9,000$ & 190 & 375 \\
$9,000-12,000$ & 200 & 400 \\
$12,000-15,000$ & 210 & 410 \\
$15,000-19,000$ & 220 & 425 \\
\hline
\end{tabular}

Commentary. Basing the learning resources budget totals on a percentage of the educational and general funds is the preferred approach, but, because this percentage represents the final stage in the budget process, it is difficult to determine during the budget planning. Capital funds are not included in the percentage.

An alternative which uses a per full-time student equivalent dollar figure will allow planning of collections and services upon a more stable basis. Table $\mathrm{C}$ is based on 1987 dollars; when there is inflation these figures should be adjusted upward accordingly. There is a correlation between services, collection, and staff size and the level of expenditures. Neither table includes capital expenditures except for acquisitions. Technological changes, automation, replacement of equipment, and other capital expenditures will require additional funds.

4.2. Local level processes should be developed so that all expenditures other than payroll originate within the learning resources program and all invoices should have the approval of the chief administrator.

Commentary. Management involves full responsibility for expenditures; no payments should be made without such written approval. Cost analyses and financial planning depend upon the control of adequate records, but these are not always the same records needed by the business offices. To the legal extent possible and to make the greatest financial savings purchases of materials should be exempt from restrictive annual bidding and should permit online ordering and standing orders for continuations.

4.3. Internal accounts shall be maintained for evaluating the flow of expenditures, monitoring encumbrances, and approving payment of invoices.

Commentary. An accurate account of expenditures in categories that are meaningful is necessary for fiscal accountability, for monitoring status of accounts, for decision making, and for planning.

4.4. The learning resources budget should provide stable funding for contractual services, equipment and materials replacement, and for maintenance of automated public and technical services.

Commentary. Many services are based on continuing support. They cannot be interrupted without serious constraint on the ability to perform effectively. The collection will become stagnant without a three to five percent replacement of older materials each year.

\section{Standard five: Services}

5.0. The learning resources program should provide a variety of services to support and expand the instructional capabilities of the institution.

Commentary. Learning resources exist to facilitate and improve learning by supporting and expanding classroom instruction and to perform the instructional function of teaching students the information-seeking skills for self-directed studies and life-long learning. As an integral part of the total educational program of the institution, learning resources provide classroom instructional as well as support services to students, faculty, and staff. In some institutions regular classroom instruction in media and bibliographical subjects and service to the community are also provided.

The primary purpose of the learning resources program is to promote learning through the academic program of the institution. To do this access to all types of information services should be available through interlibrary loan, borrowing, or use of computer databases. Most, but not all, potential services are listed in the Appendices.

Students should have access to professional assistance at all times the central facility is open as well as access to materials. Faculty members should have access to basic media production assistance and to assistance in research projects.

5.1. Priority shall be given to basic services in accordance with the mission statement; when the program includes special service components, additional staff and funding must be provided.

Commentary. Staff and budget must relate to basic services if service goals are to be met. Special services components listed in Appendix C can and do provide significant support to a learning re- 
sources program if the institution is able to afford to provide them, but they must be recognized as supplementing, not replacing, basic services. Table D shows basic services in Appendices A and B which budget and available staff make possible.

\section{TABLE D}

\section{Number of Possible Services* from Ranking of Staff and Budget}

\begin{tabular}{|l|c|c|}
\hline FTE Students & Minimum & Excellent \\
\hline Under 200 & 16 & 28 \\
$200-1,000$ & 19 & 30 \\
$1,000-3,000$ & 22 & 35 \\
$3,000-5,000$ & 26 & 40 \\
$5,000-7,000$ & 30 & 44 \\
$7,000-9,000$ & 34 & 48 \\
$9,000-11,000$ & 37 & 52 \\
$11,000-13,000$ & 40 & 54 \\
$13,000-15,000$ & 43 & 56 \\
$15,000-17,000$ & 45 & 58 \\
$17,000-19,000$ & 47 & 60 \\
\hline
\end{tabular}

${ }^{*}$ From services listed in Appendices A \& B only

5.2. The program should seek to enlarge access to the services available at the college and in the community through networking, resource sharing, online information services, and technological advances.

Commentary. Institutional self-sufficiency is no longer possible today; provision must be made to utilize new delivery systems. Timely access is the key to services. Table $\mathbf{D}$ provides a basis for evaluating the number of services which realistically can be provided based on the level of funding and staff. New technology and new services should be adopted as they become useful in meeting goals. The administrator should be prepared to bring to the attention of the faculty and administration new information formats and services as they emerge.

5.3. The services provided should meet the instructional and informational needs of students, faculty, staff, and administration, should provide professional assistance in interpretation, and should include provision for students in off-campus locations.

Commentary. Successful performance is indicated when the needs of students are met. Professional staff as part of the instructional faculty must be accessible to students and must help them gain the skills needed to be information literate. Close cooperation with the classroom faculty is mandatory. Off-campus instruction at a multi-use center must be supported by branch services or by contract services with an accessible library in accordance with ACRL's "Guidelines for Extended Campus Library Services."

5.4. Services are provided for all levels of user: students and other members of the college community.
Commentary. The two-year college has a heterogeneous population with widely different needs. Care must be taken that the services provided will meet the needs of every individual. This means that the gifted and the remedial student, the recent high school graduate and the mature adult, the physically handicapped and the limited English student can each receive the services that that individual student requires. Other campus groups have differing research and informational requirements which should be given careful consideration.

5.5. Necessary instructional equipment is available and managed in the most efficient manner to insure effective utilization.

Commentary. Equipment must be available where and when it is needed; some will be permanently located in appropriate classrooms or where materials are found. Quantity sufficient to meet peak demands and availability when non-book materials are used are necessary services. Equipment must be in good condition; obsolete equipment musi be replaced. Capital funds should also be available to insure that advantage can be taken of new technological advances.

5.6. Provision should be made for instructional support production services.

Commentary. Production services should consist, at a minimum, of visualization services, such as production of overhead transparencies, and audio services, such as recording of lectures and speeches, and duplication of these. As staff and budget allow additional production capabilities should be added to meet institutional requirements.

5.7. There shall be a program to provide to students bibliographic instruction through a variety of techniques enabling them to become information literate.

Commentary. One responsibility of the learning resources program is to provide instruction in the use of the materials and equipment available. In addition to general orientation programs, bibliographic instruction may use many different methods, including group and individual instruction and even credit courses. Traditional reference services should be geared to the provision of individualized instructional assistance at all open hours. The student should be prepared to use new information resources for a lifetime.

\section{Standard six: Collections}

6.0. The learning resources program shall make available an organized collection of materials and diversified forms of information useful in the educational process, including various forms of print and non-print media, computer software, optical storage technologies, and other formats.

Commentary. The college must be prepared to utilize new technologies for securing information as these are developed. All types of materials conveying intellectual content, artistic and literary 
works, programmed texts and packaged instruction are considered resources of information that may be used as tools of effective teaching and learning along with books, periodicals, newspapers, government documents, and microform equivalents. There is no substitute for a well-selected, immediately accessible collection.

Media materials, including those locally produced, play a vital role in the instructional program of most two-year colleges. The increasing volume of specialized, high-quality information recorded on videotape at relatively low cost gives videocassette formats a leading role in delivering current information across all disciplines. Computer software must be treated as a curricular resource for programmed learning, development of basic skills, creative research activities, and preparation for the job world. Online computer services are increasingly important as information resources along with the CD-ROM laser technologies.
Table E provides collection goals in bibliographical unit equivalents (BUE). Each cataloged item represents one BUE. Each physical volume or item represents one $\mathrm{BUE}$ except that five microcards or five uncataloged microfiche equal one BUE and fifty uncataloged slides, not in sets, or ten transparencies not in sets are one BUE. Each five films or videocassettes rented or borrowed during an academic year count as one BUE. The print collection includes microforms and serial volumes. Each serial subscription represents one BUE.

The BUE in the individual sections of Table $\mathrm{E}$ can be interchanged according to the mission of the institution. For example, an institution with a very strong music program may need to develop a strong collection of sound recordings or videorecordings much in excess of these quantitative standards but may need less of some other items. The basis for evaluation in such a case would be the total holdings for that size institution.

6.1. A collection development policy statement

\section{TABLE E}

\section{SIZE OF COLLECTION}

MINIMUM COLLECTION

\begin{tabular}{|l|c|c|c|c|c|}
\hline FTE Students & $\begin{array}{c}\text { Print } \\
\text { Items }\end{array}$ & $\begin{array}{c}\text { Serial } \\
\text { Subscriptions }\end{array}$ & $\begin{array}{c}\text { Video \& } \\
\text { Film }\end{array}$ & $\begin{array}{c}\text { Other } \\
\text { Items }^{2}\end{array}$ & $\begin{array}{c}\text { Total } \\
\text { Collection }\end{array}$ \\
\hline \hline Under 200 & 20,000 & 200 & 30 & 1,200 & 21,430 \\
$200-1,000$ & 30,000 & 230 & 45 & 1,500 & 31,775 \\
$1,000-3,000$ & 40,000 & 300 & 125 & 2,100 & 42,525 \\
$3,000-5,000$ & 60,000 & 500 & 400 & 3,000 & 63,900 \\
$5,000-7,000$ & 80,000 & 700 & 700 & 3,600 & 85,000 \\
$7,000-9,000$ & 95,000 & 850 & 750 & 4,000 & 101,600 \\
$9,000-11,000$ & 110,000 & 900 & 800 & 4,800 & 116,700 \\
$11,000-13,000$ & 125,000 & 1,000 & 850 & 5,400 & 132,250 \\
$13,000-15,000$ & 140,000 & 1,200 & 900 & 5,800 & 147,800 \\
$15,000-17,000$ & 155,000 & 1,500 & 950 & 6,000 & 163,450 \\
$17,000-19,000$ & 170,000 & 1,800 & 1,000 & 6,500 & 179,300 \\
\hline
\end{tabular}

${ }^{1}$ Print items include bound periodicals and microforms measured as described in the text. This collection assumes regular removal and replacement of obsolete, worn out, and irrelevant materials.

${ }^{2}$ Includes audiovisual and nonbook materials other than videotapes and motion picture films, including computer software.

\section{EXCELLENT COLLECTION}

\begin{tabular}{|l|c|c|c|c|c|}
\hline FTE Students & $\begin{array}{c}\text { Print } \\
\text { Items }\end{array}$ & $\begin{array}{c}\text { Serial } \\
\text { Subscriptions }\end{array}$ & $\begin{array}{c}\text { Video \& } \\
\text { Film }\end{array}$ & $\begin{array}{c}\text { Other } \\
\text { Items }\end{array}$ & $\begin{array}{c}\text { Total } \\
\text { Collection }\end{array}$ \\
\hline \hline Under 200 & 30,000 & 350 & 125 & 3,000 & 33,475 \\
$200-1,000$ & 45,000 & 400 & 140 & 3,600 & 49,140 \\
$1,000-3,000$ & 60,000 & 600 & 400 & 4,800 & 65,800 \\
$3,000-5,000$ & 85,000 & 800 & 750 & 6,600 & 93,150 \\
$5,000-7,000$ & 112,000 & 1,000 & 1,250 & 11,000 & 125,250 \\
$7,000-9,000$ & 136,000 & 1,200 & 1,600 & 13,000 & 151,800 \\
$9,000-11,000$ & 166,000 & 1,400 & 1,800 & 15,000 & 184,200 \\
$11,000-13,000$ & 200,000 & 1,600 & 2,000 & 18,000 & 221,600 \\
$13,000-15,000$ & 240,000 & 1,800 & 2,200 & 21,000 & 265,000 \\
$15,000-17,000$ & 285,000 & 2,100 & 2,400 & 24,000 & 313,500 \\
$17,000-19,000$ & 320,000 & 2,400 & 2,600 & 27,000 & 352,000 \\
\hline
\end{tabular}


shall serve as the basis for selection and acquisition of materials.

Commentary. Acquiring materials based on a written policy with clear guidelines for selection is the nature of collection development. The statement should be developed in consultation with instructional faculty, students, and administrators. Although there are many alternative ways of writing a collection development policy, the following essentials should be included:

a. The purposes for which resources are acquired.

b. The primary clientele who are to be served.

c. The kinds of materials which are to be acquired.

d. The various factors of cost and usability which will be considered in determining acquisition priorities.

e. The procedures for new types of materials, such as computer software and videocassettes, subject to copyright law.

f. The process for leasing or renting materials not readily available or too expensive to purchase.

g. Any arrangements with other institutions or agencies for cooperative collection development activities.

h. A statement in support of intellectual freedom and the Library Bill of Rights.

i. A policy on the acceptance and incorporation of gifts into the holdings which recognizes the inherent processing and storage costs.

6.2. The selection of materials should be coordinated by the professional staff, working closely with the campus community; final management decisions as to the order in which materials are to be purchased and what gifts should be accepted and processed is the responsibility of the chief administrator or designee.

Commentary. Professionally trained librarians and information specialists, because of their knowledge of the collection, are best able to give systematic attention to collection development. The importance of knowledge about existing holdings, identifying weaknesses, and determining what should and can be acquired requires systematic attention of professionals. They should have access to bibliographical tools and reviewing sources for effective collection development.

6.3. The collection shall be of sufficient scope and currency to support the curriculum as well as meet individual information needs of students and faculty.

Commentary. The mission of the college will determine the complexity of the collection but an institutional commitment to excellence should mean building and maintaining collections that adequately support: liberal arts and sciences programs to prepare students fully for transfer to four-year colleges and universities; programs that have specialized accreditation (fields such as nursing, radiologic technology, etc.); vocational and technical programs; special programs for job training, retraining, or upgrading of skills in continuing and community education services; and needed remedial programs for non-traditional or underprepared learners. Materials must be available to meet term paper assignments and classroom student reports in a broad spectrum of knowledge.

6.4. Obsolete, worn-out, and inappropriate materials should be removed based on a policy statement.

Commentary. Deselection and weeding on a regular basis is indispensable to a useful collection and should be done systematically. A written policy should govern what should be removed, what should be replaced, and what should be permanently retained. Not only do obsolete and inappropriate materials occupy expensive storage space but they also distract from other current materials containing important information. From three to five percent of the collection should be replaced annually. The condition of the collection should be reviewed regularly and needed repairs should be made.

6.5. The reference collection shall include a wide selection of standard works, with subject bibliographies and periodical indexes in print and electronic formats.

Commentary. Reference is the core of every learning resources center and the beginning point for research. The reference collection should be of sufficient breadth and depth to serve the research and informational needs of the campus community.

6.6. Learning resources should be responsible for collecting materials which document its institution's history.

Commentary. Each institution should collect all available publications and internal documents relating to the institution itself. These could include publications by the faculty as well as materials relating to the history of the college. If other institutions or libraries are not collecting materials about the history and life of the local community in which located, these could also become part of the materials to be collected.

6.7. Collections should be organized to provide users with full, efficient, and direct access.

Commentary. The choice of a classification system, the type of catalog, and the arrangement of materials are important decisions. Nationally approved systems (such as LC or Dewey) and formats (such as MARC) should be used. Uniform and multiple access through a public catalog is essential to make available information in all types of formats. The public catalog should include all print and nonprint items.

\section{Standard seven: Facilities}

7.0. The learning resources center should provide space for housing collections, for study and research, for public service and staff needs, and for basic production. 
Commentary. Flexibility is essential to cope with technological developments. Most services should be housed in a central location managed by the chief administrator. When components are located elsewhere, these should be located for the most efficient and effective access to these services. Facilities must be planned on a long-term basis, including space for an expanding collection, workspace, machines and other equipment, storage, and the needs of users. Space planning must take into account the need for computer workstations, for transmission and retrieval of information by telecommunications, for media production, and for related requirements within the building for electrical and conduit connections. Space needs of basic components require as a minimum the space indicated in Table F. Additional space should be provided when special services (such as are found in Appendix C) are included in the responsibilities of the learning resources program.

7.1. The space for user activities should accommodate a wide variety of learning and study situations, should be attractive, comfortable, designed to encourage use, and conform to approved space standards.

Commentary. Proper arrangement and sufficient space for utilization of instructional equipment and materials, for the needs of the physically handicapped, and for both isolated individual study and for conference and group study is essential. Space should also be provided for group bibliographical instruction. Display and exhibit space, preview space, and study areas for faculty are desirable. With technological developments planning for use of specialized equipment requires consideration in terms of electrical connections, cables, conduits, lights, environmental control, fire protection, security, and other factors which affect service. The increase in telecommunications may justify cable linkage to faculty offices, classrooms, and to outside locations.

7.2. Space assigned to learning resources should be restricted to the functions for which designed.

Commentary. Space designed for learning resources use should not be filled by other campus activities when these will adversely impact the learning resource program.

\section{Appendix A Checklist of basic library services}

Listed below are specific services which are considered to be normal and basic services in learning resources program budgets in two-year colleges.

Acquisition of non-print materials.

Acquisition of print materials.

Acquisition of microforms.

Archives and local history collection.

Automated online catalog.

Bibliographic instruction.

Bibliographic networks for access for interlibrary borrowing and lending.

Circulation of print materials.

Circulation of non-print materials.

Copy self service.

Government document borrowing.

Government document selective depository.

Independent study guidance.

Institutional publications reference collection.

Instructional television individualized access.

Interlibrary borrowing.

Interlibrary lending.

Laser reference searches.

Literacy training materials.

\section{TABLE F}

Facilities (ASF) for Learning Resources (Ecluding Corridors, Stairs, Rest Rooms, etc.)

\begin{tabular}{|l|l|r|r|r|r|r|r|}
\hline FTE Students & Level & \multicolumn{1}{|c|}{ Stack } & Staff & \multicolumn{1}{c|}{ User } & Production & Storage & Total \\
\hline Under 200 & Basic & 1,800 & 820 & 1,500 & 950 & 250 & 5,320 \\
& Excellent & 2,500 & 1,380 & 2,500 & 1,500 & 500 & 8,380 \\
\hline $200-1,000$ & Basic & 2,000 & 960 & 2,750 & 950 & 250 & 6,910 \\
& Excellent & 3,000 & 1,940 & 7,075 & 2,800 & 600 & 14,415 \\
\hline $1,000-3,000$ & Basic & 2,200 & 1,240 & 5,700 & 950 & 300 & 10,390 \\
& Excellent & 4,000 & 2,220 & 9,625 & 1,800 & 600 & 18,345 \\
\hline \multirow{2}{*}{$3,000-5,000$} & Basic & 3,000 & 1,940 & 8,800 & 1,800 & 1,150 & 16,690 \\
& Excellent & 5,000 & 4,040 & 14,350 & 2,500 & 2,000 & 27,890 \\
\hline \multirow{2}{5}{$, 000-9,000$} & Basic & 4,200 & 2,780 & 14,350 & 2,200 & 1,350 & 24,880 \\
& Excellent & 6,200 & 4,880 & 24,475 & 3,000 & 2,200 & 40,755 \\
\hline \multirow{2}{*}{$, 000-12,000$} & Basic & 6,200 & 3,060 & 23,775 & 3,000 & 1,750 & 37,785 \\
& Excellent & 10,000 & 5,580 & 27,775 & 6,000 & 2,300 & 51,655 \\
\hline $12,000-15,000$ & Basic & 9,000 & 4,600 & 27,775 & 5,000 & 1,950 & 48,325 \\
& Excellent & 12,500 & 7,540 & 35,475 & 8,000 & 2,400 & 65,915 \\
\hline \multirow{2}{*}{$15,000-19,000$} & Basic & 12,000 & 5,160 & 37,675 & 6,000 & 2,150 & 62,985 \\
& Excellent & 16,000 & 8,380 & 43,175 & 9,000 & 2,500 & 79,055 \\
\hline
\end{tabular}


Microcomputer literacy.

Machine-assisted cataloging of books.

Machine-assisted cataloging of audiovisuals.

Machine-assisted reference searching.

Microcomputers for public use.

Microform cataloging.

Microform print service.

Online public access catalog.

Physical access to materials.

Processing of audiovisuals.

Processing microforms.

Processing print materials.

Reference services.

Reserve book service.

Special collections services.

Telefacsimile service.

Telephone reference service.

Term paper counseling.

Union card catalog.

\section{Appendix B}

\section{Checklist of basic audiovisual} and learning technology services

Listed below are services which are considered to be normal and basic services in two-year college learning resources program budgets. This list may not include future technologies and services.

Adult literacy laboratory.

Audiovisual equipment services.

Closed circuit television.

Copyright consultation.

Darkroom services.

Equipment distribution.

Equipment maintenance.

Equipment repair.

Equipment specifications.

Graphic art layouts.

Group television viewing.

Identification photography.

Instructional design and development counseling.

Interactive television.

Inventory of audiovisual equipment.

Listening services.

Motion picture photography.

News photography.

Photography for slides.

Preview services for faculty.

Production of instructional materials on limited basis.

Production of sound slide programs.

Satellite communication down.

Scripting of audiovisual presentations.

Scripting of television modules.

Sound cassette duplication.

Sound cassette editing.

Sound cassette recording.

Telecourse availability information.

Television editing.

Television one camera video production.
Television multicamera video production.

Television off-air recording.

Television remote recording.

\section{Appendix C \\ Checklist of special services components}

This list includes new technologies and peripheral roles which, if assigned to the learning resources program, will require capital funds, space, personnel, and operational budgets in excess of those included in tables $A$ to $F$. Inclusion of programs in this list is not advocacy for these services as part of the learning resources program but recognition that some institutions have included them in the supervisory responsibilities of the chief administrator.

Adult literacy program direction.

Auto-tutorial laboratory.

Cable televised instruction.

Career counseling.

College catalog production.

College press.

Computer laboratory.

Copy shop (not self service).

Cross-divisional programs.

Government document full depository.

Institutional records center and archives.

Instructional design office.

Language laboratory.

Learning laboratory.

Library technician curricular program.

Materials preservation laboratory.

Media technician curricular program.

Museum.

Print shop.

Public library branch services.

Radio on-air broadcasting.

Radio station maintenance.

Records management.

Satellite communication up.

Teleconferencing and distant learning.

Telecourse administration.

Television on-air broadcasting.

Television course broadcast-level production.

Television station maintenance.

Testing.

Text-book rental service.

Tutoring program supervision.

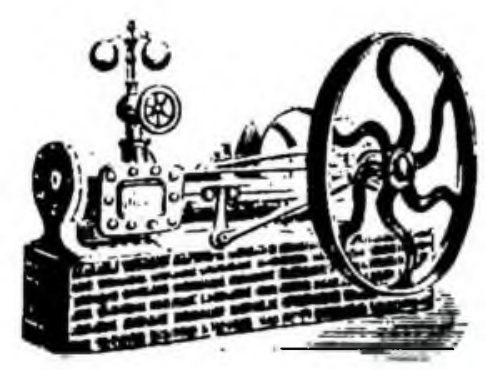



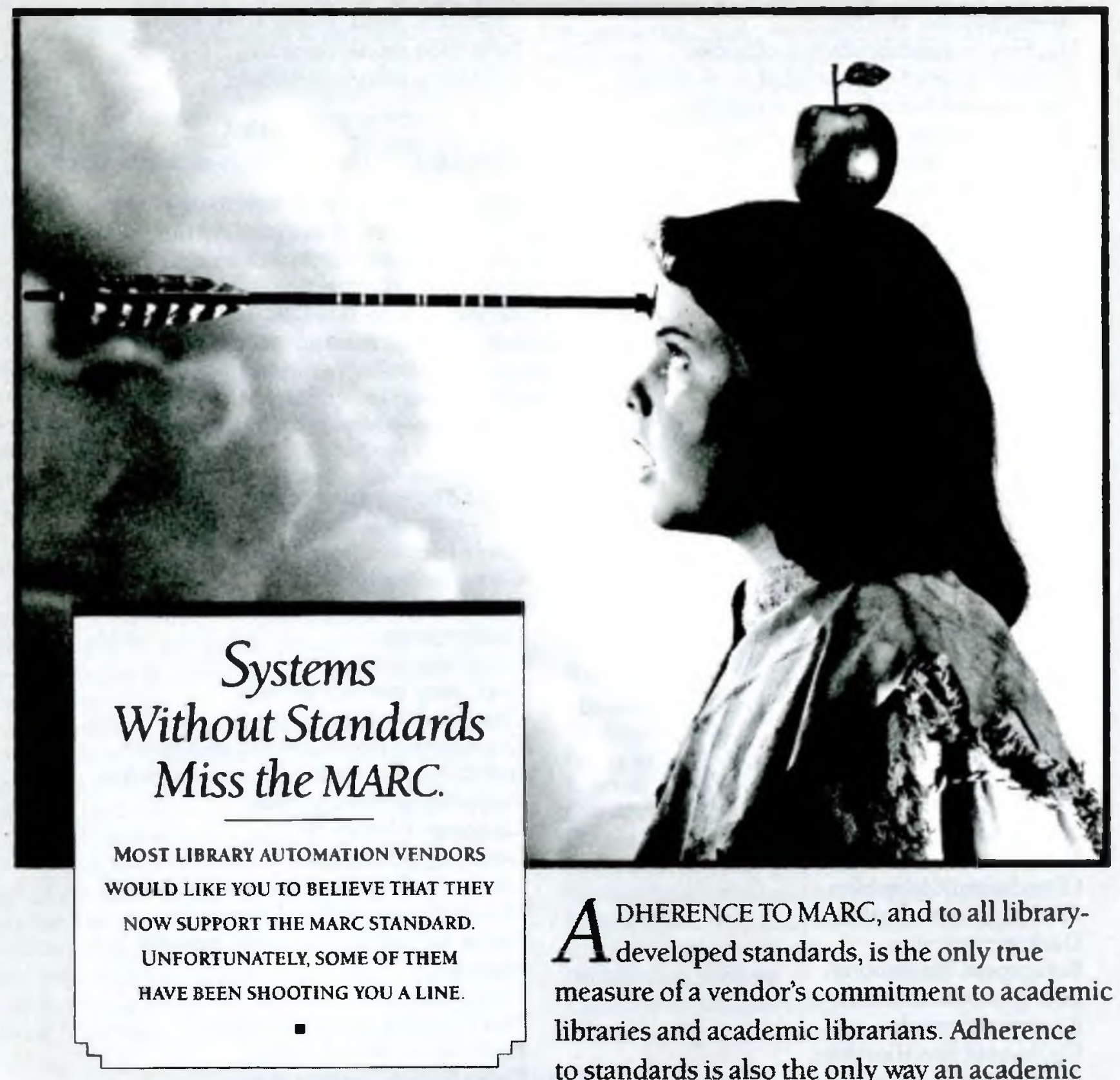

WOULD LIKE YOU TO BELIEVE THAT THEY

DHERENCE TO MARC, and to all library-
developed standards, is the only true measure of a vendor's commitment to academic libraries and academic librarians. Adherence to standards is also the only way an academic

library can guarantee the long-range success of its automation system. CAMPUS-WIDE NETWORKING, for example, as well as the ability to access off-campus data sources, requires careful adherence to automation communications standards. Data Research's use of Ethernet and DECnet/OSI provides you with that power now. SUPPORT OF YOUR CHOICE of workstations from a wide variety of vendors is also possible using ATLAS-A Total Library Automation System

from Data Research-because of our support of communications standards. SPECIALIZED DATABASES can be easily built, fully indexed and even made available through the Public Access Catalog because of our use of full-MARC bibliographic and authority records. What's more, Data Research has committed to support the emerging NISO Common Command Language standard for PACs, ensuring that ATLAS users will be at the forefront of tomorrow's movement toward simplified interlibrary resource sharing. WITH FULIY INTEGRATED modules for cataloging, circulation, PAC, acquisitions, materials booking, reserve book room, full-text database searching and a wide range of other services, ATLAS offers academic libraries the most powerful functionality in the industry. Call us today to find out how this power is flexible enough

to serve dozens of diverse academic ATLAS instal-

lations, including community colleges like Maricopa County Community College in Phoenix and prestigious universities like Tufts.

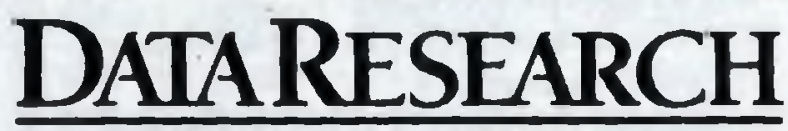

